\title{
MORPHOLOGICAL CHARACTERIZATION AND EVALUATION OF NINETEEN GLADIOLUS GERMPLASM
}

\author{
M. A. Hoque ${ }^{1^{*}}$ and S. Mahmud ${ }^{1}$
}

\begin{abstract}
Nineteen gladiolus germplasms were characterized and evaluated in the Research Field of the Department of Horticulture, Bangabandhu Sheikh Mujibur Rahman Agricultural University, Gazipur, during November 2017 to May 2018 for identifying suitable line(s) to release as a variety for commercial cultivation. The accession $\mathrm{G}_{8}$ produced the highest number of shoots (3.3) and effective shoots (3.0) per hill. The accessions that produced flower stalk within 75 days of planting included BARI gladiolus- $3\left(\mathrm{G}_{1}, 58.7\right.$ days), $\mathrm{G}_{2}$ (62.3 days), $\mathrm{G}_{3}$ (65.7 days), BARI gladiolus- 5 ( $\mathrm{G}_{4}, 61.3$ days), $\mathrm{G}_{5}$ (55.7 days), BARI gladiolus- $6\left(\mathrm{G}_{7}, 71.3\right.$ days $), \mathrm{G}_{10}$ (74.0 days), $\mathrm{G}_{14}$ (73.3 days), $\mathrm{G}_{15}$ (75.0 days) and $\mathrm{G}_{19}$ (67.3 days). The highest rachis length was recorded in BARI gladiolus- $3(53.7 \mathrm{~cm})$ which was statistically similar with the rachis length of $\mathrm{G}_{6}(46.0 \mathrm{~cm}), \mathrm{G}_{10}(46.3 \mathrm{~cm})$, $\mathrm{G}_{11}(47.0 \mathrm{~cm})$ and BARI gladiolus- $1\left(\mathrm{G}_{12}, 46.3 \mathrm{~cm}\right)$ but significantly differed with other accessions. Most of the accessions in general, produced more than 10 florets per spike. Vase life of the accessions varied and $\mathrm{G}_{11}$ had the highest vase life of 9-11 days and this was close to 9-10 days in $\mathrm{G}_{9}$ and 8-9 days in BARI gladiolus- $3\left(\mathrm{G}_{1}\right), \mathrm{G}_{8}, \mathrm{G}_{10}, \mathrm{G}_{17}, \mathrm{G}_{18}$ and $G_{19}$. The highest number of corm per hill was recorded in $G_{8}(10.3)$ followed by $\mathrm{G}_{5}$ (8.7), $\mathrm{G}_{16}$ (8.3), $\mathrm{G}_{17}$ (7.7) and BARI gladiolus- 3 (6.7). Number of cormels per hill ranged from 9.0-941.7 with an average of 237.0. Based on various plant, flower colour, corm and cormel production characters, the gladiolus accessions $\mathrm{G}_{3}, \mathrm{G}_{5}, \mathrm{G}_{8}, \mathrm{G}_{9}, \mathrm{G}_{10}, \mathrm{G}_{11}$, $\mathrm{G}_{14}, \mathrm{G}_{16}, \mathrm{G}_{17}, \mathrm{G}_{18}$ and $\mathrm{G}_{19}$ may be considered for further study.
\end{abstract}

Keywords: Gladiolus, cormel, commercial cultivation, variety development.

\section{Introduction}

Once, only the well-off bought flowers to colour festivals. Now, even the low to mid income groups love to present flowers on beautiful moments. So, the present position of floriculture in our country is more or less uprising. About 10,000 hectares of land is now devoted to flower cultivation in Bangladesh (Rakibuzzaman et al., 2018). As days go, demand for flower is increasing very rapidly. In valentines' day of 2009, flower of TK 2 crore were sold in Dhaka in 2 days (Khan, 2013).
In Bangladesh, commercial floriculture is expanding very rapidly. Today, floriculture has emerged as a lucrative profession in Bangladesh with a much higher potential for returns than most other fields and horticultural crops (Sultana, 2003). Bangladesh is well suited for cut flower and ornamental production due to the favorable climatic and other conditions like cheap land, low labour cost, relatively low capital investment and high value addition (Dadlani, 2004). Bangladesh has very good potentialities to become an important supplier of flower and ornamental

\footnotetext{
${ }^{1}$ Department of Horticulture, Bangabandhu Sheikh Mujibur Rahman Agricultural University, Gazipur 1706, Bangladesh.

*Corresponding author: azizul@bamrau.edu.bd
} 
plants for Asia, the Middle East and Europe (Momin, 2006).

Gladiolus (Gladiolus $s p$ ) belongs to the family Iridaceae is an important cut flower grown worldwide including Bangladesh. It is sold at almost every corner of city areas by the retailers. In our country, its demand is increasing because of its elegant spike, rich varied colours and long vase life. Now-adays, the farmers are commercially cultivating this crop in Bangladesh (Islam and Haque, 2011). Gladiolus coming into play in recent times occupied the top position with a percent market share of 31.11 (Rakibuzzaman et al., 2018). Presently, the Floriculture Division of BARI is conducting research on gladiolus along with other flower crops. They have already released 6 (six) varieties of gladiolus which is not sufficient and more varieties need to be released. By this time, 280 numbers of flower and ornamental germplasm including gladiolus are being collected from different sources (Ara et al., 2010); which is not sufficient. So, to enrich the genetic resources of this crop, more germplasm from home and abroad are needed to be collected for further evaluation with a view to improvement and development of the crops. Some progressive farmers, nurserymen and private entrepreneurs have already been collected different gladiolus germplasm from abroad and other sources. Those genotypes need to be collected for evaluation and conservation properly to develop and enrich germplasm pool. Selection of better plant type from the collected germplasm can be of immense value for further improvement of this crop. It is, therefore considered indispensable to collect, characterize, evaluate and finally, to select the promising one(s) among the selected materials. Hence, the present study on gladiolus was undertaken.

\section{Materials and Methods}

The experiment was conducted at the research field of the Department of Horticulture, Bangabandhu Sheikh Mujibur Rahman Agricultural University, Gazipur from November 2017 to May 2018. Nineteen gladiolus germplasm were previously collected from farmer's field and nurseries of Godkhali, Benapole, Jessore, Bogra, Savar areas through direct visit and were included in the experiment. Cut flower stick of all collected germplasm are presented in Plate 1 and 2. The germplasm were numbered as $G_{1}, G_{2}, G_{3}, G_{4}$, $\mathrm{G}_{5}, \mathrm{G}_{6}, \mathrm{G}_{7}, \mathrm{G}_{8}, \mathrm{G}_{9}, \mathrm{G}_{10}, \mathrm{G}_{11}, \mathrm{G}_{12}, \mathrm{G}_{13}, \mathrm{G}_{14}, \mathrm{G}_{15}$, $\mathrm{G}_{16}, \mathrm{G}_{17}, \mathrm{G}_{18}$ and $\mathrm{G}_{19}$. Out of these germplasm, $\mathrm{G}_{1}, \mathrm{G}_{4}, \mathrm{G}_{7}$ and $\mathrm{G}_{12}$ has already been released by the Bangladesh Agricultural Research Institute as BARI gladiolus- 3, BARI gladiolus- 5, BARI gladiolus- 6 and BARI gladiolus- 1 , respectively. The unit plot size was $1.2 \mathrm{~m} \mathrm{X}$ $1.2 \mathrm{~m}$. Medium sized $(3.5-4.5 \mathrm{~cm})$ corms of different gladiolus germplasm were planted at about 6-9 $\mathrm{cm}$ depth in the plot maintaining a spacing of $30 \mathrm{~cm} \mathrm{X} 15 \mathrm{~cm}$. The experiment was set up on November 12, 2017 following Randomized Complete Block Design (RCBD) with 3 replications. Manures and fertilizers were applied at the rate of cowdung- $10 \mathrm{t} /$ ha, Urea- $300 \mathrm{~kg} / \mathrm{ha}$, TSP- $375 \mathrm{~kg} / \mathrm{ha}$, MoP$300 \mathrm{~kg} / \mathrm{ha}$, Boric acid- $12.0 \mathrm{~kg} / \mathrm{ha}$ and Zinc sulphate- $8.0 \mathrm{~kg} / \mathrm{ha}$ (Azad, 2017). Entire quantity of manures and fertilizers except urea were applied during final land preparation and mixed with soil. Half of urea was top dressed after 25 days of planting and rest half was applied during spike initiation stage. Different intercultural operations like irrigation, 
weeding, earthing up, stacking, pesticide and fungicide application were performed as needed. The spikes were cut when lower one or two florets showed color but still in tight bud stage. The cut spikes were kept into water to study the vase life. Corms and cormels were harvested only when the leaves turned into brown colour (Mukhopadhyay, 1995). The collected data were statistically analyzed using computer MSTAT-C program. Mean separation was done by Duncan's Multiple Range Test (DMRT).

\section{Results and Discussion}

Plant characteristics of 19 germplasm have been presented in Table 1. Results revealed that base colour of the germplasm were either green or tan (pale brown) or light tan or light pink. Number of leaf was found to be varied significantly. The highest number of leaves per plant was recorded in $G_{15}$ (11.7) which was statistically similar to $G_{3}$ (11.3). The lowest number of leaves per plant (8.0) was recorded in $\mathrm{G}_{5}, \mathrm{G}_{8}, \mathrm{G}_{10}$ and $\mathrm{G}_{13}$. This result was in agreement with the findings of Hossain et al. (2011), who found it ranged from 8.50-12.25. Number of shoot per hill varied significantly, which ranged from 1.0-3.3 with an average of 2.1. Likewise, significant variation was found in number of effective shoot per hill which varied from 1.0-3.0 with an average of 1.5. The accession $\mathrm{G}_{8}$ produced the highest number of shoot (3.3) and effective shoots (3.0) per hill. It indicated that all the shoots of gladiolus did not effectively produce inflorescence. Variation was observed as to the days to flower spike initiation. The accession $\mathrm{G}_{16}$ took the highest time (81.3 days) for spike initiation; whereas, $\mathrm{G}_{5}$ took the lowest (55.7 days). Days to spike initiation is very important as it determines the earliness or lateness of the flower crop. The accessions that produced flower stalk within 75 days of planting included BARI Gladiolus- 3 (58.7 days), $G_{2}$ (62.3 days), $G_{3}$ (65.7 days), BARI Gladiolus- 5 (61.3 days), $\mathrm{G}_{5}$ (55.7 days), BARI Gladiolus- 6 ( 71.3 days), $\mathrm{G}_{10}$ (74.0 days), $\mathrm{G}_{14}$ ( 73.3 days), $\mathrm{G}_{15}$ (75.0 days) and $\mathrm{G}_{19}$ (67.3 days). Tirkey et al. (2018) reported to have spikes of gladiolus after 53.4-67.0 days of planting. Variation in days to spike initiation seem to be genetically controlled as reported by Pragya et al. (2010) in gladiolus. Regarding diseases, leaf blight was found to infect in BARI Gladiolus- $3\left(\mathrm{G}_{1}\right), \mathrm{G}_{6}, \mathrm{G}_{13}$ and $\mathrm{G}_{15}$; whereas, cut worm infestation was found in BARI Gladiolus- $3\left(\mathrm{G}_{1}\right), \mathrm{G}_{2}$, BARI Gladiolus- $5\left(\mathrm{G}_{4}\right)$ and $\mathrm{G}_{15}$ (Table 1).

Plant height in gladiolus is important as it determines lodging of the crop. Longer plant tends to be lodged and needs to be staked. Plant height in different accessions found to be varied (Fig. 1). The longest plant was observed in the accession BARI gladiolus- 5 $(92.3 \mathrm{~cm})$, which was statistically different from all other accessions. The accession $\mathrm{G}_{2}$ had a plant height of $76.3 \mathrm{~cm}$ and it was similar to the plant height of BARI gladiolus$3(65.0 \mathrm{~cm}), \mathrm{G}_{3}(74.3 \mathrm{~cm})$ and $\mathrm{G}_{16}(72.7 \mathrm{~cm})$ but significantly differed from rest of the accessions. The shortest plant $(42.0 \mathrm{~cm})$ was observed in $\mathrm{G}_{13}$. The accessions $\mathrm{G}_{5}(51.7 \mathrm{~cm})$, $\mathrm{G}_{6}(54.0 \mathrm{~cm})$, BARI gladiolus- $6(60.0 \mathrm{~cm})$, $\mathrm{G}_{8}(53.7 \mathrm{~cm}), \mathrm{G}_{9}(55.3 \mathrm{~cm}), \mathrm{G}_{10}(59.0 \mathrm{~cm}), \mathrm{G}_{11}$ $(54.3 \mathrm{~cm})$, BARI gladiolus- $1(52.7 \mathrm{~cm}), \mathrm{G}_{14}$ $(59.7 \mathrm{~cm}), \mathrm{G}_{17}(59.3 \mathrm{~cm}), \mathrm{G}_{18}(58.7 \mathrm{~cm})$ and $\mathrm{G}_{19}(56.7 \mathrm{~cm})$ produced medium sized plants, where the plant height ranged from $50-60 \mathrm{~cm}$ (Fig. 1). Hossain et al. (2011) recorded more or less similar range of $46.52-58.65 \mathrm{~cm}$ plant 
Table 1. Plant characteristics of nineteen gladiolus germplasm

\begin{tabular}{|c|c|c|c|c|c|c|c|}
\hline Accession & $\begin{array}{c}\text { Base colour } \\
\text { of plant }\end{array}$ & $\begin{array}{c}\text { Number } \\
\text { of leaves / } \\
\text { Plant }\end{array}$ & $\begin{array}{l}\text { Number of } \\
\text { shoot/hill }\end{array}$ & $\begin{array}{l}\text { Number of } \\
\text { effective } \\
\text { shoot/hill }\end{array}$ & $\begin{array}{l}\text { Days to } \\
1^{\text {st }} \text { spike } \\
\text { initiation }\end{array}$ & Disease & Insect \\
\hline $\mathrm{G}_{1}$ & Green & $10.0 \mathrm{~cd}$ & $1.0 \mathrm{~d}$ & $1.0 \mathrm{~d}$ & $58.7 \mathrm{hi}$ & LB & Cut worm \\
\hline $\mathrm{G}_{2}$ & Tan & $10.0 \mathrm{~cd}$ & $1.3 \mathrm{~cd}$ & $1.0 \mathrm{~d}$ & $62.3 \mathrm{fgh}$ & None & Cut worm \\
\hline $\mathrm{G}_{3}$ & Tan & $11.3 \mathrm{ab}$ & $1.3 \mathrm{~cd}$ & $1.0 \mathrm{~d}$ & $65.7 \mathrm{fg}$ & None & None \\
\hline $\mathrm{G}_{4}$ & Light tan & 9.3 cde & $1.7 \mathrm{bcd}$ & $1.7 \mathrm{bcd}$ & $61.3 \mathrm{gh}$ & None & Cut worm \\
\hline $\mathrm{G}_{5}$ & Light pink & $8.0 \mathrm{f}$ & $3.0 \mathrm{ab}$ & $1.7 \mathrm{bcd}$ & $55.7 \mathrm{i}$ & None & None \\
\hline $\mathrm{G}_{6}$ & Tan & $10.0 \mathrm{~cd}$ & $3.0 \mathrm{ab}$ & $1.7 \mathrm{bcd}$ & $78.3 \mathrm{abc}$ & LB & None \\
\hline $\mathrm{G}_{7}$ & Tan & $8.3 \mathrm{ef}$ & $2.3 \mathrm{a}-\mathrm{d}$ & $1.7 \mathrm{bcd}$ & $71.3 \mathrm{de}$ & None & None \\
\hline $\mathrm{G}_{8}$ & Light tan & $8.0 \mathrm{f}$ & $3.3 \mathrm{a}$ & $3.0 \mathrm{a}$ & 76.0 a-d & None & None \\
\hline $\mathrm{G}_{9}$ & Tan & 8.7 ef & $2.0 \mathrm{a}-\mathrm{d}$ & $1.3 \mathrm{~cd}$ & $78.0 \mathrm{abc}$ & None & None \\
\hline $\mathrm{G}_{10}$ & Light tan & $8.0 \mathrm{f}$ & $2.3 \mathrm{a}-\mathrm{d}$ & $1.0 \mathrm{~d}$ & $74.0 \mathrm{bcd}$ & None & None \\
\hline $\mathrm{G}_{11}$ & Green & 8.3 ef & $1.3 \mathrm{~cd}$ & $1.0 \mathrm{~d}$ & $78.7 \mathrm{abc}$ & None & None \\
\hline $\mathrm{G}_{12}$ & Green & $10.3 \mathrm{bc}$ & $1.0 \mathrm{~d}$ & $1.0 \mathrm{~d}$ & $80.0 \mathrm{a}$ & None & None \\
\hline $\mathrm{G}_{13}$ & Tan & $8.0 \mathrm{f}$ & $2.7 \mathrm{abc}$ & $2.3 \mathrm{abc}$ & $78.0 \mathrm{abc}$ & LB & None \\
\hline $\mathrm{G}_{14}$ & Green & $10.0 \mathrm{~cd}$ & $1.0 \mathrm{~d}$ & $1.0 \mathrm{~d}$ & $73.3 \mathrm{~cd}$ & None & None \\
\hline $\mathrm{G}_{15}$ & Tan & $11.7 \mathrm{a}$ & $2.3 \mathrm{a}-\mathrm{d}$ & $1.0 \mathrm{~d}$ & $75.0 \mathrm{~b}-\mathrm{d}$ & LB & Cut worm \\
\hline $\mathrm{G}_{16}$ & Light tan & $9.0 \mathrm{def}$ & $3.3 \mathrm{a}$ & $1.7 \mathrm{bcd}$ & $81.3 \mathrm{a}$ & None & None \\
\hline $\mathrm{G}_{17}$ & Light tan & $9.0 \mathrm{def}$ & $3.3 \mathrm{a}$ & $2.7 \mathrm{ab}$ & $78.0 \mathrm{abc}$ & None & None \\
\hline $\mathrm{G}_{18}$ & Tan & $10.3 \mathrm{bc}$ & $1.3 \mathrm{~cd}$ & $1.0 \mathrm{~d}$ & $79.3 \mathrm{ab}$ & None & None \\
\hline $\mathrm{G}_{19}$ & Light tan & 8.7 ef & $2.3 \mathrm{a}-\mathrm{d}$ & $1.3 \mathrm{~cd}$ & 67.3 ef & None & None \\
\hline Mean & - & 9.3 & 2.1 & 1.5 & 72.3 & - & - \\
\hline CV (\%) & - & 7.06 & 17.43 & 13.48 & 4.20 & - & - \\
\hline
\end{tabular}

Tan= Pale brown and LB= Leaf blight

$\mathrm{G}_{1}=$ BARI gladiolus- $3, \mathrm{G}_{4}=$ BARI gladiolus- $5, \mathrm{G}_{7}=$ BARI gladiolus- 6 and $\mathrm{G}_{12}=$ BARI gladiolus- 1 .

height in the studied genotypes of gladiolus; whereas, Singh et al. (2017) recorded a range from $80.3-134.7 \mathrm{~cm}$ plant height with a mean of $112.0 \mathrm{~cm}$ in ten hybrids of gladiolus. As the genotypes of present study has been collected from farmers field and they are hopefully open pollinated; so, the variation in plant height of different gladiolus genotypes might be due to the genetic difference as well as growing environment and management practices.
The spike length, rachis length, number of side spike and number of floret per spike varied significantly among the germplasm. The longest spike was found in BARI gladiolus- $3(72.0 \mathrm{~cm})$ which was statistically similar to $G_{10}(69.7 \mathrm{~cm})$ but differed from rest of the accessions. In majority of the accessions, spike length was recorded as more than $50.0 \mathrm{~cm}$. Rachis length differed from $19.0 \mathrm{~cm}$ to $53.7 \mathrm{~cm}$ with an average of 36.4 


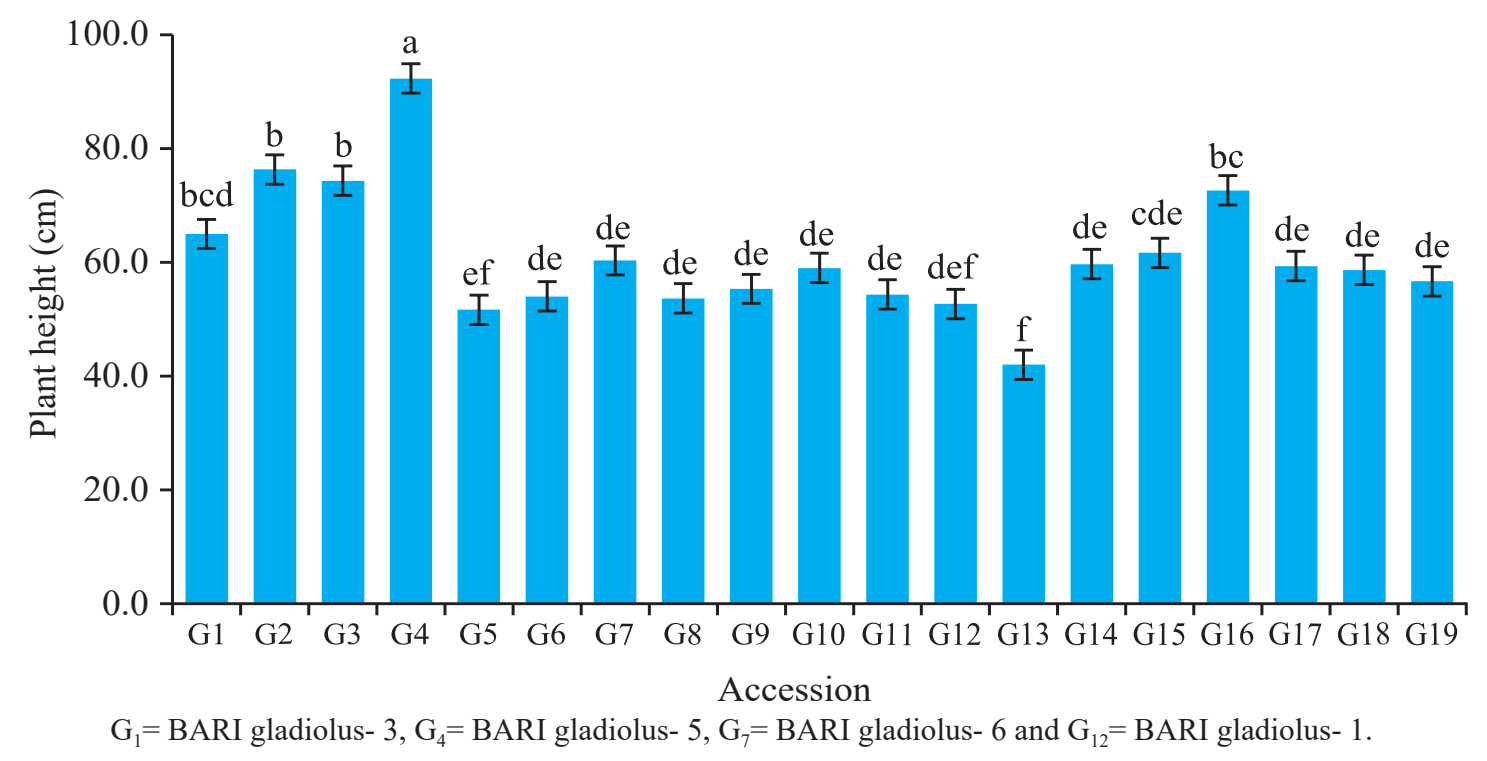

Fig. 1. Plant height $(\mathrm{cm})$ at spike initiation stage influenced by gladiolus germplasm.

$\mathrm{cm}$. The highest rachis length was recorded in BARI gladiolus- $3(53.7 \mathrm{~cm})$ which was statistically similar to the rachis length of $\mathrm{G}_{6}$ $(46.0 \mathrm{~cm}), \mathrm{G}_{10}(46.3 \mathrm{~cm}), \mathrm{G}_{11}(47.0 \mathrm{~cm})$ and BARI gladiolus- $1(46.3 \mathrm{~cm})$ but significantly differed from other accessions. Tirkey et al. (2018) recorded a variable rachis length in six gladiolus genotypes that ranged from $37.3 \mathrm{~cm}$ to $62.7 \mathrm{~cm}$. The variation in different characters among varieties might be due to variation of genetic traits and the effect of prevailing environmental conditions (Kumar, 2015). Regarding number of side spike, only 5 accessions produced side spikes and majority of the accessions had no side spikes.

Significant variation was found regarding number of floret per spike, which ranged from 7.0-15.7. The highest number of florets per spike was recorded in $\mathrm{G}_{11}$ (15.7) followed by $\mathrm{G}_{10}$ (14.8), BARI gladiolus- 3 (14.0) and $\mathrm{G}_{2}$ (13.7). The accession $\mathrm{G}_{13}$ (7.0) had the lowest number of florets per spike (Fig. 2). In general, most of the accession produced more than 10 florets per spike. Hossain et al. (2011) reported a range of 8.4-14.3 florets per spike, while studied with five different genotypes of gladiolus. Whereas, Tirkey et al. (2018) recorded to have 11.2- 15.0 florets per spike, while working with six genotypes of gladiolus and Rashmi (2006) obtained 14.1- 16.7 florets per spike while working with 11 genotypes of gladiolus.

Variable flower characters were observed and recorded in the studied accessions (Table 3). Nineteen accessions had different floret colour and marking (Plate 1 and Plate 2). Although, BARI gladiolus- $3\left(\mathrm{G}_{1}\right)$ and $\mathrm{G}_{6}$ produced white coloured floret but they differed regarding floret marking. The florets of BARI gladiolus- $3\left(G_{1}\right)$ had pink scar inside; while, the florets of $\mathrm{G}_{6}$ had red butterfly scar inside. The accession BARI gladiolus- $5\left(\mathrm{G}_{4}\right)$ and 
Table 2. Flowering characteristics of nineteen gladiolus germplasm

\begin{tabular}{|c|c|c|c|}
\hline Accession & Spike length $(\mathrm{cm})$ & Rachis length (cm) & Number of side spike \\
\hline $\mathrm{G}_{1}$ & $72.0 \mathrm{a}$ & $53.7 \mathrm{a}$ & $1.0 \mathrm{~b}$ \\
\hline $\mathrm{G}_{2}$ & $55.3 \mathrm{~cd}$ & $39.0 \mathrm{~b}-\mathrm{e}$ & $0.0 \mathrm{c}$ \\
\hline $\mathrm{G}_{3}$ & $66.0 \mathrm{~b}$ & $43.0 \mathrm{bc}$ & $0.0 \mathrm{c}$ \\
\hline $\mathrm{G}_{4}$ & $61.7 \mathrm{bc}$ & $41.7 \mathrm{bc}$ & $0.0 \mathrm{c}$ \\
\hline $\mathrm{G}_{5}$ & $53.7 \mathrm{~cd}$ & $40.7 \mathrm{bcd}$ & $1.0 \mathrm{~b}$ \\
\hline $\mathrm{G}_{6}$ & $53.3 \mathrm{~cd}$ & $46.0 \mathrm{ab}$ & $0.0 \mathrm{c}$ \\
\hline $\mathrm{G}_{7}$ & 42.3 ef & $36.7 \mathrm{c}-\mathrm{f}$ & $0.0 \mathrm{c}$ \\
\hline $\mathrm{G}_{8}$ & 40.6 ef & $27.8 \mathrm{~g}$ & $0.0 \mathrm{c}$ \\
\hline $\mathrm{G}_{9}$ & $51.0 \mathrm{~d}$ & 38.7 b-e & $0.0 \mathrm{c}$ \\
\hline $\mathrm{G}_{10}$ & $69.7 \mathrm{ab}$ & $46.3 \mathrm{ab}$ & $2.0 \mathrm{~b}$ \\
\hline $\mathrm{G}_{11}$ & $57.0 \mathrm{~cd}$ & $47.0 \mathrm{ab}$ & $0.0 \mathrm{c}$ \\
\hline $\mathrm{G}_{12}$ & $61.7 \mathrm{bc}$ & $46.3 \mathrm{ab}$ & $0.7 \mathrm{bc}$ \\
\hline $\mathrm{G}_{13}$ & $37.7 \mathrm{f}$ & $25.3 \mathrm{gh}$ & $0.7 \mathrm{bc}$ \\
\hline $\mathrm{G}_{14}$ & $54.3 \mathrm{~cd}$ & $31.0 \mathrm{efg}$ & $0.0 \mathrm{c}$ \\
\hline $\mathrm{G}_{15}$ & $41.0 \mathrm{ef}$ & $28.3 \mathrm{fg}$ & $0.0 \mathrm{c}$ \\
\hline $\mathrm{G}_{16}$ & $47.7 \mathrm{de}$ & $29.0 \mathrm{fg}$ & $0.0 \mathrm{c}$ \\
\hline $\mathrm{G}_{17}$ & $52.7 \mathrm{~cd}$ & $33.0 \mathrm{~d}-\mathrm{g}$ & $0.0 \mathrm{c}$ \\
\hline $\mathrm{G}_{18}$ & 38.7 ef & $19.3 \mathrm{~h}$ & $0.0 \mathrm{c}$ \\
\hline $\mathrm{G}_{19}$ & 38.7 ef & $19.0 \mathrm{~h}$ & $0.0 \mathrm{c}$ \\
\hline Mean & 52.4 & 36.4 & 0.3 \\
\hline CV $(\%)$ & 9.40 & 12.61 & 15.80 \\
\hline
\end{tabular}

$\mathrm{G}_{1}=$ BARI gladiolus- $3, \mathrm{G}_{4}=$ BARI gladiolus- $5, \mathrm{G}_{7}=$ BARI gladiolus- 6 and $\mathrm{G}_{12}=$ BARI gladiolus- 1 .

$\mathrm{G}_{8}$ had also produced similar colour (yellow) of florets but they also differed in floret marking. The floret colour of the accessions $\mathrm{G}_{3}, \mathrm{G}_{5}, \mathrm{G}_{8}, \mathrm{G}_{9}, \mathrm{G}_{10}, \mathrm{G}_{11}, \mathrm{G}_{14}, \mathrm{G}_{16}, \mathrm{G}_{17}, \mathrm{G}_{18}$ and $\mathrm{G}_{19}$ was very attractive. Floret breadth and length in the studied accessions also varied. The highest breadth $(12.0 \mathrm{~cm})$ and length $(12.2 \mathrm{~cm})$ were recorded in $\mathrm{G}_{15}$, indicated the largest flower size. The accession $G_{11}$ produced the smallest sized florets among the accessions with a breadth and length of $6.5 \mathrm{~cm}$ and $6.2 \mathrm{~cm}$, respectively (Table 3 ). Bhat et al. (2017) recorded a breadth range of 6.0-12.0 cm in fifty studied genotypes of gladiolus, which supported the present study. Vase life in the accessions varied and $\mathrm{G}_{11}$ had the highest vase life (9-11 days) followed by $\mathrm{G}_{9}$ (9-10 days), BARI gladiolus- 3 (8-9 days), $\mathrm{G}_{8}$ (8-9 days), $\mathrm{G}_{10}$ (8-9 days), $\mathrm{G}_{17}$ (8-9 days), $\mathrm{G}_{18}$ (8-9 days) and $\mathrm{G}_{19}$ (8-9 days). 


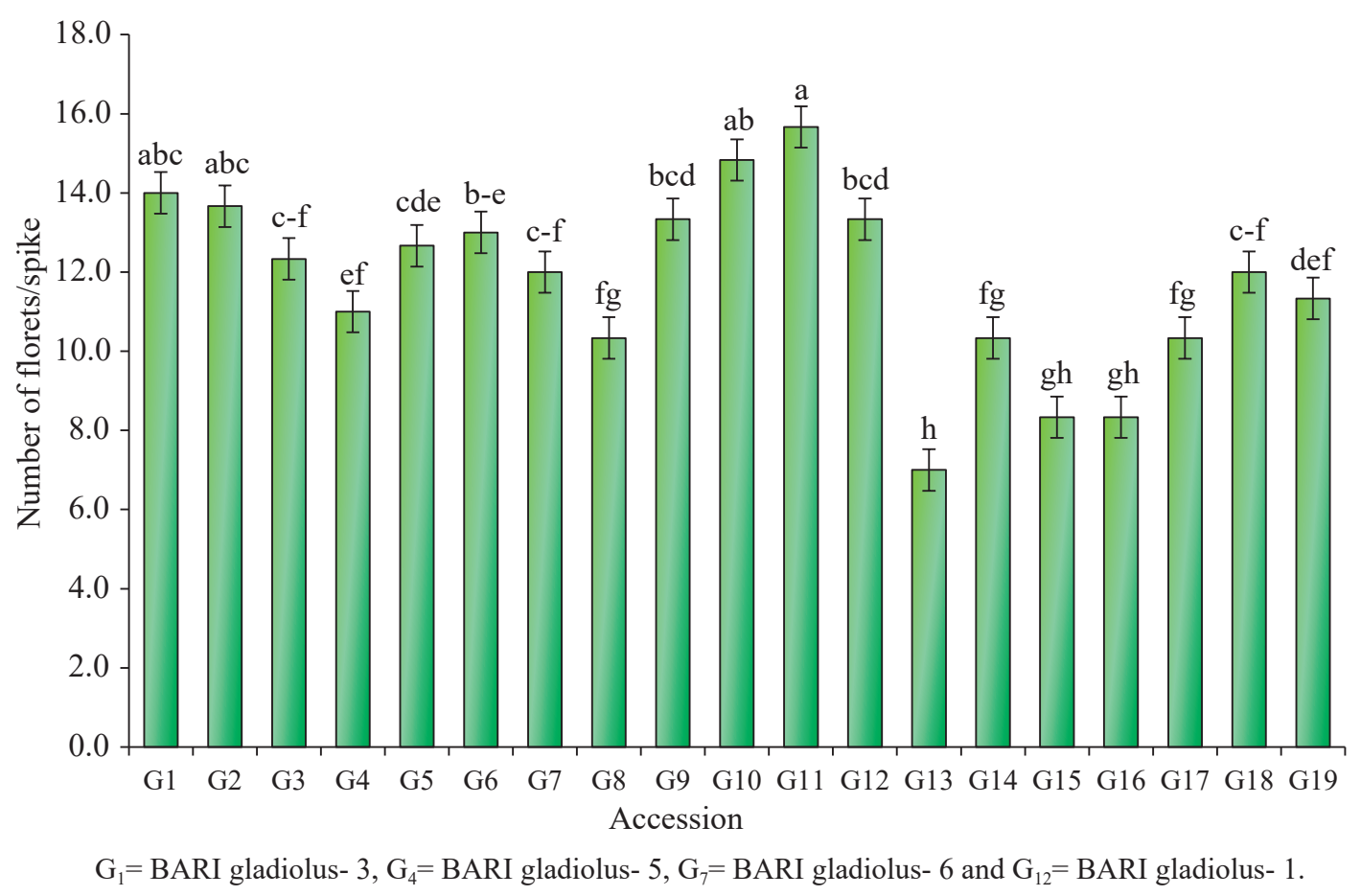

Fig. 2. Number of florets/spike in different gladiolus germplasm.

Corms and cormels characteristics of nineteen gladiolus accessions are presented in Table 4 . The highest number of corms was recorded in $\mathrm{G}_{8}(10.3)$, which differed statistically from other accessions. The accessions $\mathrm{G}_{9}, \mathrm{G}_{11}$ and $\mathrm{G}_{14}$ produced the lowest number of corms per hill (1.3). Number of corms per hill is very important in gladiolus as the corms are the sources of seed for the following years. Weight of individual corm was also found to be varied significantly among the accessions. The highest corm weight was obtained from in BARI gladiolus- 5 (75.7 g) and the lowest in $\mathrm{G}_{18}(12.3 \mathrm{~g})$. Likewise, the diameter of large corm was observed the highest $(6.6 \mathrm{~cm})$ in BARI gladiolus- 5 $\left(\mathrm{G}_{4}\right)$ and the lowest $(3.6 \mathrm{~cm})$ in $\mathrm{G}_{10}$ and $\mathrm{G}_{18}$ (Table 4). Number of cormels per hill was also varied widely among the accessions and ranged from 9.0-941.7 with an average of 237.0. Individual weight of cormels in the accessions was also varied and ranged from $0.1-1.1 \mathrm{~g}$. The accession $\mathrm{G}_{6}$ produced the largest cormel (Table 4). 

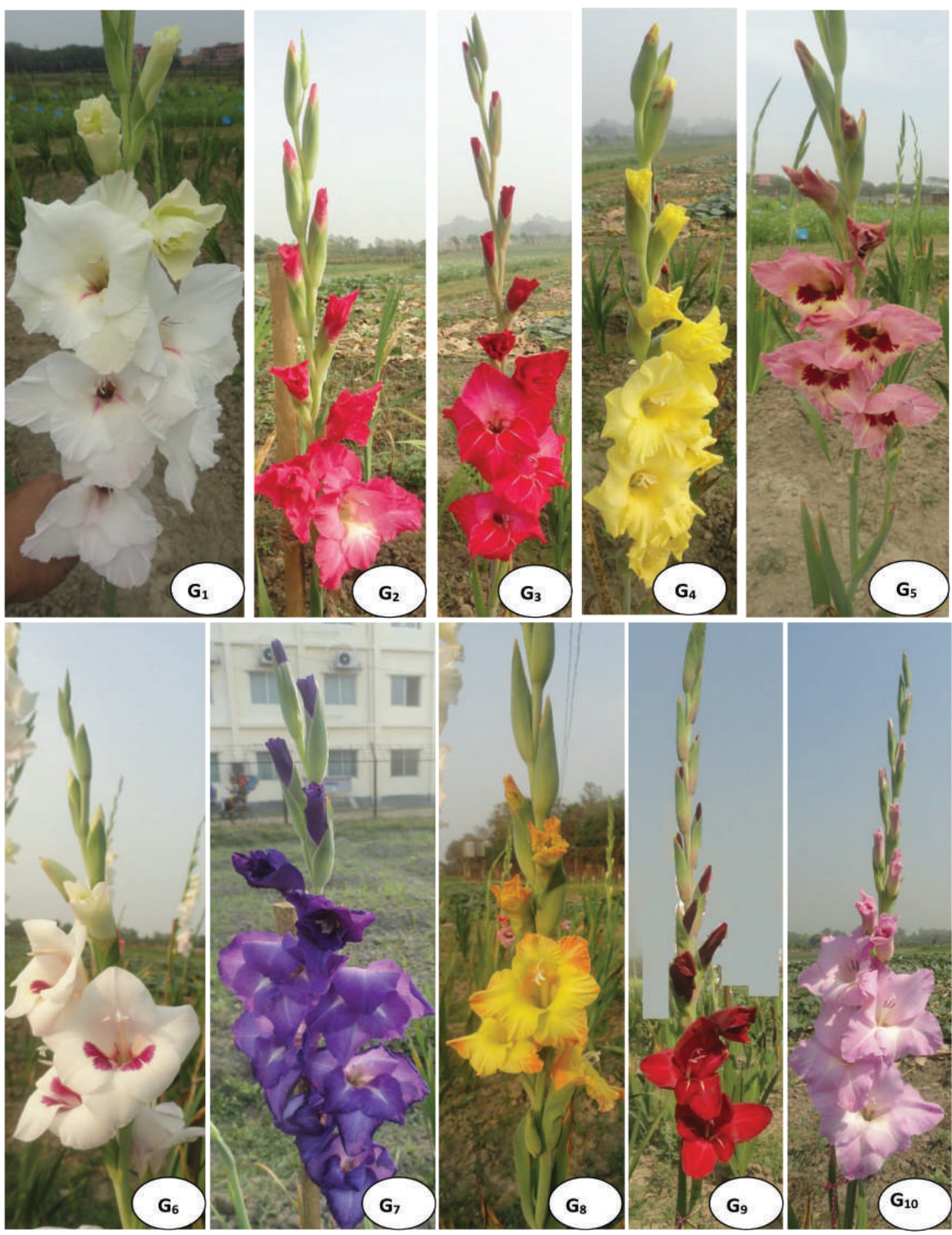

Plate 1. Flower spikes of different gladiolus germplasm $\left(G_{1}-G_{10}\right)$. 

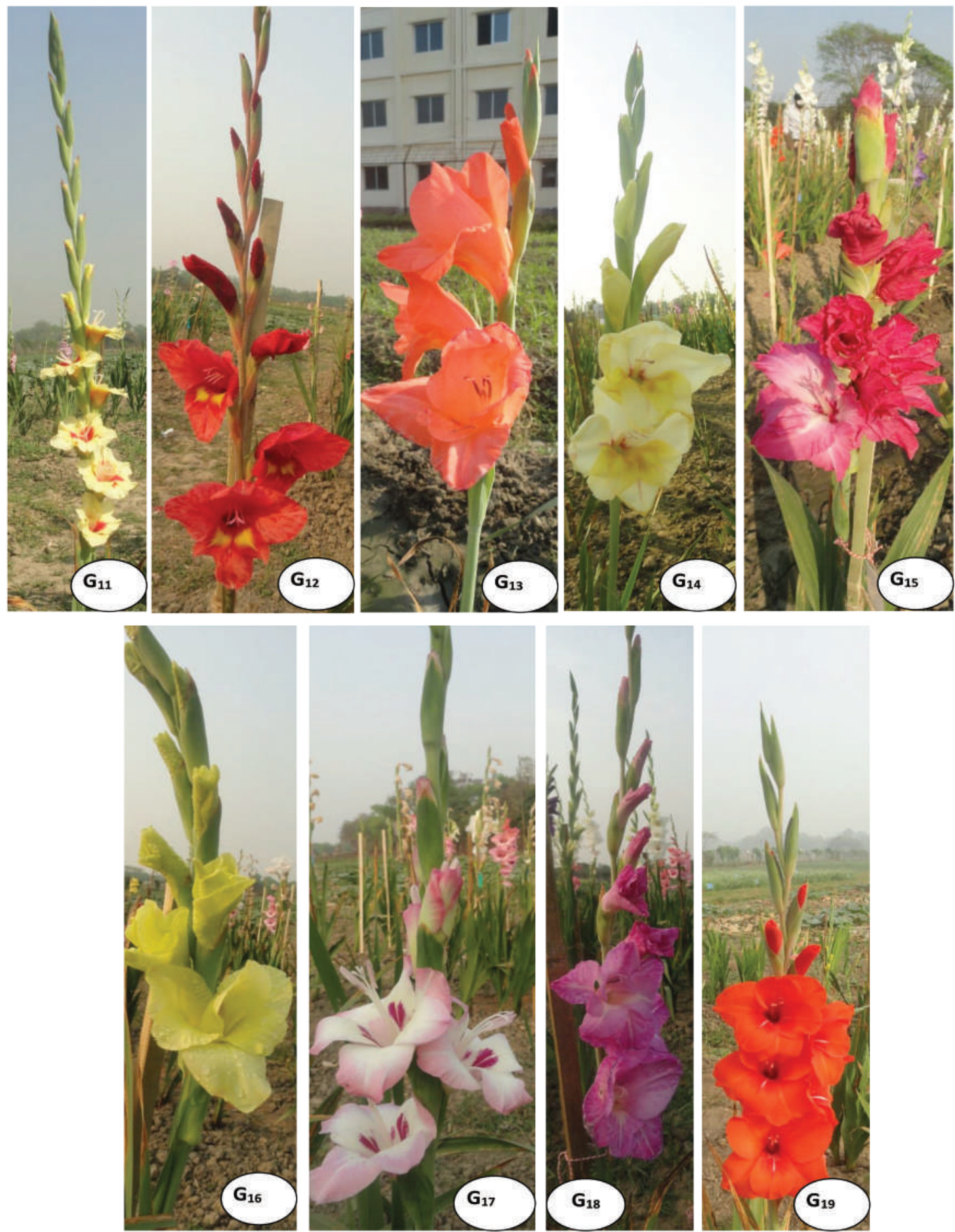

Plate 2. Flower spikes of different gladiolus germplasm $\left(G_{11}-G_{19}\right)$. 
Table 3. Floret characteristics of nineteen gladiolus germplasm

\begin{tabular}{|c|c|c|c|c|c|}
\hline Accession & Colour of florets & Floret marking & $\begin{array}{l}\text { Floret length } \\
\quad(\mathrm{cm})\end{array}$ & $\begin{array}{c}\text { Floret } \\
\text { breadth }(\mathrm{cm})\end{array}$ & $\begin{array}{l}\text { Vase life } \\
\text { (days) }\end{array}$ \\
\hline $\mathrm{G}_{1}$ & White & Pink scar inside & $11.3 \mathrm{ab}$ & $11.7 \mathrm{a}$ & $8-9$ \\
\hline $\mathrm{G}_{2}$ & Light red & White scar inside & $10.7 \mathrm{bc}$ & $10.0 \mathrm{~b}$ & $6-7$ \\
\hline $\mathrm{G}_{3}$ & Deep red & White scar inside & $10.7 \mathrm{bc}$ & $10.1 \mathrm{~b}$ & $7-8$ \\
\hline $\mathrm{G}_{4}$ & Yellow & None & $10.8 \mathrm{bc}$ & $10.1 \mathrm{~b}$ & $6-8$ \\
\hline $\mathrm{G}_{5}$ & Light pink & Deep red butterfly scar inside & $10.2 \mathrm{c}$ & $10.0 \mathrm{~b}$ & $7-9$ \\
\hline $\mathrm{G}_{6}$ & White & Red butterfly scar inside & $8.3 \mathrm{efg}$ & $8.2 \mathrm{~d}$ & $5-7$ \\
\hline $\mathrm{G}_{7}$ & Violet & White scar inside & $7.8 \mathrm{fg}$ & $8.3 \mathrm{~d}$ & $7-8$ \\
\hline $\mathrm{G}_{8}$ & Yellow & Orange scar on side of petal & $7.5 \mathrm{gh}$ & $6.8 \mathrm{gh}$ & $8-9$ \\
\hline $\mathrm{G}_{9}$ & Tan & Velvety, white scar inside & 8.5 ef & $8.0 \mathrm{de}$ & $9-10$ \\
\hline $\mathrm{G}_{10}$ & Light violet & White scar inside & $8.0 \mathrm{fg}$ & $7.3 \mathrm{efg}$ & $8-9$ \\
\hline $\mathrm{G}_{11}$ & Light yellow & Deep red butterfly scar inside & $6.2 \mathrm{i}$ & $6.5 \mathrm{~h}$ & $9-11$ \\
\hline $\mathrm{G}_{12}$ & Brick Red & Yellow butterfly scar inside & 8.5 ef & $8.0 \mathrm{de}$ & $7-8$ \\
\hline $\mathrm{G}_{13}$ & Light orange & None & $6.8 \mathrm{hi}$ & $7.2 \mathrm{fgh}$ & $6-7$ \\
\hline $\mathrm{G}_{14}$ & Cream & Yellow scar inside & 8.7 ef & $8.5 \mathrm{~cd}$ & $7-8$ \\
\hline $\mathrm{G}_{15}$ & Red & White scar inside & $12.2 \mathrm{a}$ & $12.0 \mathrm{a}$ & $6-7$ \\
\hline $\mathrm{G}_{16}$ & $\begin{array}{l}\text { Light yellow } \\
\text { (Biscuit color) }\end{array}$ & None & $9.9 \mathrm{~cd}$ & $9.2 \mathrm{c}$ & $7-8$ \\
\hline $\mathrm{G}_{17}$ & Light pink & Inside white with red butterfly scar & $6.8 \mathrm{hi}$ & $6.8 \mathrm{gh}$ & $8-9$ \\
\hline $\mathrm{G}_{18}$ & Pink & White scar inside & $9.1 \mathrm{de}$ & $8.5 \mathrm{~cd}$ & $8-9$ \\
\hline $\mathrm{G}_{19}$ & Orange & White scar inside & $8.0 \mathrm{fg}$ & $7.8 \mathrm{def}$ & $8-9$ \\
\hline Mean & - & - & 9.0 & 8.7 & - \\
\hline CV $(\%)$ & - & - & 5.88 & 5.03 & - \\
\hline
\end{tabular}

$\mathrm{G}_{1}=$ BARI gladiolus- $3, \mathrm{G}_{4}=$ BARI gladiolus- $5, \mathrm{G}_{7}=$ BARI gladiolus- 6 and $\mathrm{G}_{12}=$ BARI gladiolus- 1 . 
Table 4. Corms and cormels characteristics of nineteen gladiolus germplasm

\begin{tabular}{|c|c|c|c|c|c|c|}
\hline Accession & $\begin{array}{l}\text { Number of } \\
\text { corms/hill }\end{array}$ & $\begin{array}{l}\text { Weight of } \\
\text { individual } \\
\text { corm }(\mathrm{g})\end{array}$ & $\begin{array}{l}\text { Diameter of the } \\
\text { largest corm }(\mathrm{cm})\end{array}$ & $\begin{array}{l}\text { Number of } \\
\text { cormels/hill }\end{array}$ & $\begin{array}{l}\text { Weight of cormel/ } \\
\text { hill }(\mathrm{g})\end{array}$ & $\begin{array}{l}\text { Weight of } \\
\text { individual } \\
\text { cormel }(\mathrm{g})\end{array}$ \\
\hline $\mathrm{G}_{1}$ & $6.7 \mathrm{~cd}$ & $46.5 \mathrm{~cd}$ & $5.8 \mathrm{bc}$ & 941.7 a & 266.9 a & 0.3 \\
\hline $\mathrm{G}_{2}$ & $5.7 \mathrm{de}$ & $20.4 \mathrm{ij}$ & $4.5 \mathrm{f}-\mathrm{i}$ & $451.3 \mathrm{~b}$ & $117.2 \mathrm{bc}$ & 0.3 \\
\hline $\mathrm{G}_{3}$ & $5.3 \mathrm{def}$ & $55.0 \mathrm{~b}$ & $6.2 \mathrm{ab}$ & 213.3 cde & $90.5 \mathrm{~cd}$ & 0.4 \\
\hline $\mathrm{G}_{4}$ & $5.3 \mathrm{def}$ & $75.7 \mathrm{a}$ & $6.6 \mathrm{a}$ & $146.7 \mathrm{~d}-\mathrm{g}$ & $85.2 \mathrm{~d}$ & 0.6 \\
\hline $\mathrm{G}_{5}$ & $8.7 \mathrm{~b}$ & $34.8 \mathrm{ef}$ & 5.3 cde & $398.3 \mathrm{~b}$ & $131.5 \mathrm{~b}$ & 0.3 \\
\hline $\mathrm{G}_{6}$ & $3.3 \mathrm{hi}$ & 24.9 ghi & $3.9 \mathrm{ij}$ & $9.0 \mathrm{~g}$ & $9.5 \mathrm{~g}$ & 1.1 \\
\hline $\mathrm{G}_{7}$ & $3.7 \mathrm{ghi}$ & $20.3 \mathrm{ij}$ & $4.1 \mathrm{~g}-\mathrm{j}$ & $38.7 \mathrm{fg}$ & $17.4 \mathrm{~g}$ & 0.4 \\
\hline $\mathrm{G}_{8}$ & $10.3 \mathrm{a}$ & $40.5 \mathrm{de}$ & $5.1 \mathrm{def}$ & $316.7 b c$ & $94.9 \mathrm{~cd}$ & 0.3 \\
\hline $\mathrm{G}_{9}$ & $1.3 \mathrm{j}$ & $20.1 \mathrm{ij}$ & $4.7 \mathrm{efg}$ & $43.7 \mathrm{fg}$ & $22.0 \mathrm{fg}$ & 0.5 \\
\hline $\mathrm{G}_{10}$ & $4.3 \mathrm{e}-\mathrm{h}$ & $12.4 \mathrm{k}$ & $3.6 \mathrm{j}$ & $337.7 \mathrm{bc}$ & $51.7 \mathrm{e}$ & 0.2 \\
\hline $\mathrm{G}_{11}$ & $5.0 \mathrm{efg}$ & $22.0 \mathrm{hi}$ & $4.6 \mathrm{fgh}$ & 70.7 efg & $16.3 \mathrm{~g}$ & 0.2 \\
\hline $\mathrm{G}_{12}$ & $2.3 \mathrm{ij}$ & $14.1 \mathrm{jk}$ & $3.9 \mathrm{j}$ & $38.7 \mathrm{fg}$ & $86.5 \mathrm{~d}$ & 2.2 \\
\hline $\mathrm{G}_{13}$ & $5.7 \mathrm{de}$ & $28.5 \mathrm{fgh}$ & $5.1 \mathrm{def}$ & $418.3 \mathrm{~b}$ & $109.5 \mathrm{bcd}$ & 0.3 \\
\hline $\mathrm{G}_{14}$ & $1.3 \mathrm{j}$ & $22.3 \mathrm{hi}$ & $4.0 \mathrm{hij}$ & $27.0 \mathrm{fg}$ & $8.1 \mathrm{~g}$ & 0.3 \\
\hline $\mathrm{G}_{15}$ & $1.3 \mathrm{j}$ & $21.5 \mathrm{hi}$ & $4.7 \mathrm{fg}$ & $311.3 \mathrm{bc}$ & $116.8 \mathrm{bc}$ & 0.4 \\
\hline $\mathrm{G}_{16}$ & $8.3 \mathrm{~b}$ & $47.6 \mathrm{c}$ & $5.8 \mathrm{bcd}$ & $229.0 \mathrm{~cd}$ & $57.5 \mathrm{e}$ & 0.3 \\
\hline $\mathrm{G}_{17}$ & $7.7 \mathrm{bc}$ & $31.1 \mathrm{fg}$ & 4.9 ef & $185.0 \mathrm{c}-\mathrm{f}$ & 48.2 ef & 0.3 \\
\hline $\mathrm{G}_{18}$ & $3.3 \mathrm{hi}$ & $12.3 \mathrm{k}$ & $3.6 \mathrm{j}$ & $226.3 \mathrm{~cd}$ & 33.8 efg & 0.1 \\
\hline $\mathrm{G}_{19}$ & $4.0 \mathrm{fgh}$ & $38.9 \mathrm{e}$ & $5.6 \mathrm{bcd}$ & $100.0 \mathrm{~d}-\mathrm{g}$ & $18.8 \mathrm{~g}$ & 0.2 \\
\hline Mean & 4.9 & 31.0 & 4.9 & 237.0 & 72.8 & 0.3 \\
\hline CV (\%) & 15.53 & 12.25 & 7.35 & 14.96 & 20.83 & - \\
\hline
\end{tabular}

$\mathrm{G}_{1}=$ BARI gladiolus- $3, \mathrm{G}_{4}=$ BARI gladiolus- $5, \mathrm{G}_{7}=$ BARI gladiolus- 6 and $\mathrm{G}_{12}=$ BARI gladiolus- 1 .

\section{Conclusions}

The collected gladiolus germplasm varied in different characters with released varieties. Based on flower colour and other characters, the gladiolus accessions $\mathrm{G}_{3}, \mathrm{G}_{5}, \mathrm{G}_{8}, \mathrm{G}_{9}$, $\mathrm{G}_{10}, \mathrm{G}_{11}, \mathrm{G}_{14}, \mathrm{G}_{16}, \mathrm{G}_{17}, \mathrm{G}_{18}$ and $\mathrm{G}_{19}$ may be considered for further study.

\section{Acknowledgements}

The authors acknowledge the Research Management wing (RMW) of BSMRAU to offer fund for conducting the experiment and successful implementation of the project activities.

\section{References}

Ara, K. A., S. M. Sharifuzzaman and M. Rafiuddin. 2010. Collection and evaluation of chrysanthemum genotypes. Annual Research Report on Flower and Ornamentals, HRC, BARI. Pp. 11-15.

Azad, A. K, B. K. Goshami, M. L. Rahman, P. K. Malaker, M. S. Hasan and M. H. H. Rahman. 2017. Krishi Projukti Hatboi (Handbook on Agro-technology), $7^{\text {th }}$ Edition, Bangladesh 
Agricultural Research Institute, Gazipur 1701, Bangladesh. Pp. 321-324.

Bhat, Z. A., I. T. Nazki, Nelofar and B. Hamid. 2017. Evaluation of gladiolus cultivars for growth, flowering, spike yield and corm yield under temperate regions of Kashmir. Indian Hort. J. 7(3/4): 203-207.

Dadlani, N. K. 2004. Prospects of floriculture in Bangladesh. A Consultancy Report. FAO/ UNDP (IHNDP/BGD/97/04).

Hossain, M. D., K. H. Talukder, M. Asaduzzaman, F. Mahmud, N. Amin and M.A. Sayed. 2011. Study on morphological characteristics of different genotypes of gladiolus flower. $J$. Sci. Foundation. 9(1\& 2): 01-08.

Islam, M. S. and A. F. M. E. Haque. 2011. Performance of gladiolus under protected cultivation in the rainy season. Bangladesh J. Agril. Res. 36(2): 285-290.

Khan, R. A. 2013. Flower market development in Bangladesh. Paper presented in the national seminar on floriculture development in Bangladesh held on 18 May, 2013 at the BARC Conference Room-1, Farmgate, Dhaka.

Kumar, M. 2015. Morphological characterization of gladiolus (Gladiolus hybridus Hort.) germplasm. J. Plant Dev. Sci. 7(4) : 359-362.

Momin, M. A. 2006. Floriculture survey in Bangladesh. A Consultancy Report. FAO/ UNDP (IHNDP/ BGD/ 97/06).

Mukhopadhyay, A. 1995. Gladiolus. Publications and information division, ICAR, New Delhi. India. 35 P.
Pragya, J. K. Ranjan, B. L. Attri, B. Das, H. Krishna and N. Ahmed. 2010. Performance of gladiolus genotypes for cut flower and corm production under high altitude of Uttarakhand. Indian J. Hort. 67: 389-90.

Rakibuzzaman, M., S. Rahul, M. R. Jahan, M. I. Ifaz and A. F. M. J. Uddin. 2018. Flower industry in Bangladesh: Exploring floriculture potential. Int. J. Bus. Soc. Sci. Res. 7(1): 50-56. [Cited from http://www. ijbssr.com/currentissueview/14013304]

Rashmi, L. 2006. Evaluation of promising hybrids of gladiolus. An unpublished MS thesis. Department of horticulture, college of agriculture, Dharwad university of agricultural sciences, Dharwad, Karnataka, India.

Singh, N., S. Tamta, A. K. Pal, T. S. Rana, R. K. Roy and S. K. Tewari. 2017. Characterization of gladiolus germplasm using morphological, physiological and molecular markers. Biochem. Genet. Springer Science. [https:// doi.org/10.1007/s 10528017-9835-4].

Sultana, N. 2003. Floriculture exports from Bangladesh. A paper presented in international floriculture conference on $6^{\text {th }}$ November, 2003, BARC, Farmgate, Dhaka.

Tirkey, T., S. Tamrakar, G. Sharma and M. Sahu. 2018. Effect of planting dates and cultivars on floral characters of gladiolus (Gladiolus grandiflorus) under Chhattisgarh Plains. Int. J. Curr. Microbiol. App. Sci. 7(06): 1964-1976 [doi: https://doi.org/10.20546/ ijcmas.2018.706.233]. 